In addition to some hundreds of important papers published with numerous collaborators, Lowry wrote several useful books; the last of these, on "Optical Rotatory Power", was issued last year and will long remain a standard work on the subject. The immense amount of accurate experimental work which Lowry has left on record secures him a permanent place in the history of the science to which he was devoted. His old colleagues and students in the laboratory of physical chemistry which he built up at Cambridge will remember him as a staunch friend, an inspiring teacher and an indefatigable worker who has passed too soon from their ranks.

WM. J. POPE.

\section{Prof. H. R. Briton-Jones}

\section{$\mathrm{P}$} ROF. HARRY RICHARD BRITON-JONES whose untimely death occurred in Trinidad on November 3, following an operation for appendicitis, will be mourned by a wide circle of friends, scientific colleagues and past and present students of the Imperial College of Tropical Agriculture. He was born in 1893 and educated at Llandovery College, of which he was a scholar. $\mathrm{He}$ entered King's College, London, in 1912, proceeding to the Royal College of Science in 1913, where he took the associateship and, later, the diploma of the Imperial College. In 1915 he was commissioned in the R.G.A. and he gained the M.C. on active service, being eventually invalided from shell-shock, with the rank of captain. Attracted to the study of plant diseases, he re-entered the Royal College of Science to equip himself for phytopathological research ; a short period was also spent at the Royal Botanic Gardens, Kew, in systematic study of the fungi parasitic on plants.

At the end of 1919, Briton-Jones was appointed mycologist in the Egyptian Department of Agriculture, but he left in 1923 to become mycologist at the Horticultural Research Station of the University of Bristol at Long Ashton. He was appointed professor of mycology and bacteriology at the Imperial College of Tropical Agriculture, Trinidad, in 1926 and dean of the College in the following year ; he acted as principal on several occasions.

In Egypt, Briton-Jones devoted himself largely to the study of cotton and cereal diseases, publishing in 1925 the main results in a memoir entitled "Mycological Work in Egypt during the Period 1920-1922". At Long Ashton he was led to consider the influence of the nutrition and cultural management of the host plant on its susceptibility to parasitic disease, a subject which afterwards became increasingly predominant in his mind. While there, he published work on the cause of die-back of fruit trees, a problem not yet fully elucidated but in which the factors of nutritional and soil-moisture unbalance which he emphasized probably play a considerable part. On proceeding to Trinidad, he applied the same considerations to the diseases of permanent tropical crops, especially cacao and coco-nuts. His book on "The Diseases and Curing of Cacao" (Macmillan and Co., Ltd., London, 1934) was followed by a similar work on coco-nut diseases, but he did not live to see it published.

Briton-Jones's outstanding virtue as a mycologist was his very practical outlook. His opposition to academic views was sometimes carried to extremes, but he was intensely in earnest, and his enthusiasm in combating theory by practical experience often supplied a useful corrective. He helped to place plant pathology on a wider basis than that of parasitology, and in this his influence has been spread by his students to many parts of the Empire. As a teacher, he was the right man in the right place; to his students he was a friend, and he shared in their college life-he was a keen Rugger player-and gained their affection to an unusual degree.

E. J. B.

\section{Lieut.-Colonel R. H. Elliot}

Lieut.-Colonel Robert Henry Elliot, whose death on November 9 we regret to record, had a distinguished career in ophthalmology as well as in other walks of life. The son of a colonel in the Army, he was educated at Bedford School and St. Bartholomew's Hospital, where he was a prizeman of the medical school. He had a brilliant career as a student and qualified M.B., B.S. (London) with honours in three subjects. He took his fellowship of the Royal College of Surgeons of England in 1892 and in the same year took the D.P.H. Cambridge and entered the Indian Medical Service. At Netley he was Montefiore scholar and medallist and Maclean prizeman in military surgery.

Soon after arrival in India, Elliot joined the Southern Presidency. His work there naturally led to an extended experience in ophthalmology, and he was superintendent of the Government Ophthalmic Hospital, Madras, and professor of ophthalmology in the Medical College from 1904 until 1914. While on leave in 1904, he completed his qualifications by obtaining the Sc.D. (Edin.) and the M.D. (Lond.).

Elliot's name will always be remembered for the work he did on sclero-corneal trephining in cases of glaucoma. The operation is known by his name all over the world, and was a notable advance in the surgical treatment of a disease the origin of which is in many cases obscure, and which has in the past led to a great deal of blindness.

Elliot's literary output was considerable. His chief works were handbooks on glaucoma and an account of sclero-corneal trephining, each of which went to a second edition. Besides this, he wrote an excellent text-book on tropical ophthalmology, which has been translated into a number of foreign languages, as well as smaller works. His work brought him many distinctions at home and abroad. Returning home in 1915, Elliot settled in London and quickly acquired a very large practice. For a number of years he was ophthalmic surgeon to the Prince of Wales General Hospital, Tottenham; and he was Consulting Ophthalmic Surgeon to the Hospital for Tropical Diseases.

Apart from his work as an ophthalmic surgeon, Elliot was an authority on snakes and a first-class amateur conjurer. His last book was published 